Research Journal of Applied Sciences 7 (2): 92-99, 2012

ISSN: $1815-932 \mathrm{X}$

(C) Medwell Journals, 2012

\title{
Shea Butter Tree (Vitellaria paradoxa Gaertn.) Fruit Yield in Relation to Dendrometric Traits and Land-Use in Uganda
}

\author{
${ }^{1}$ Patrick Byakagaba, ${ }^{2}$ Gerald Eilu, ${ }^{2}$ John Bosco L. Okullo, \\ ${ }^{2}$ Edward N. Mwavu and ${ }^{2}$ Susan B. Tumwebaze \\ ${ }^{1}$ Department of Environment Management, ${ }^{2}$ Department of Forestry, \\ Biodiversity and Tourism, Makerere University, P.O. Box 7062, Kampala, Uganda
}

\begin{abstract}
Vitellaria paradoxa is one of the dominant and important fruit tree species in savanna woodlands of Africa. The butter extracted from the nuts of this tree is used in medicine, food and cosmetics. However, there is limited information on factors that influence fruit production in $V$. paradoxa. Researchers conducted a 2 years study to assess fruit yield of this tree in relation to dendrometric traits and land use types in four localities within the Shea Belt of Uganda. We determined the patterns of fruit yield by land use categories; inter-annual variability in fruit yield between successive years and different tree sizes. We also developed fruit yield prediction models based on dendrometric traits and land use types. Sampling was done in sites with old fallows, young fallows and cultivated fields within selected districts of the Shea belt in Uganda. Four plots of $50 \times 50 \mathrm{~m}$ were established systematically in each land use type. Fruiting trees were randomly selected and fruit yield assessed over two fruiting seasons. Current fields and young fallows had better fruit yield compared to old fallows. Fruit yield varied between the 2 years of data collection. Most dendrometric traits exhibited a weak positive correlation with fruit yield. The likelihood of fruit yield increase was high in current fields than fallows. Trees with few branches at first forking of the stem were more likely to have better fruit yield than those with many branches. Therefore, Dbh, land use types and number of branches at first forking were suitable explanatory variables for fruit yield prediction. Farmers need to preserve large DBH trees with few branches at first forking under conditions of either current fields or young fallow if fruit production is the main objective of managing Shea parklands.
\end{abstract}

Key words: Inter-annual variability, fruit production, DBH, crown diameter, Vitellaria savanna

\section{INTRODUCTION}

Vitellaria paradoxa (Shea butter tree or Karite) is an indigenous tree species in the savanna woodlands of Africa (Hall et al., 1996). It belongs to the family Sapotaceae within the genus Vitellaria with two subspecies i.e., $V$. paradoxa ssp. nilotica and V. paradoxa ssp. paradoxa (Hall and Hindle, 1995). $V$. paradoxa ssp. nilotica occurs in Eastern Africa (through South Sudan, Northern and North Eastern parts Uganda, Western Ethiopia and North Eastern parts of Democratic Republic of Congo) in areas of altitude 650-1600 masl. V. paradoxa ssp. paradoxa is found in West Africa from eastern parts of Central African Republic westwards to Senegal in areas of altitude between 100-600 m (Hall et al., 1996).

$V$. paradoxa is one of the most important fruit trees in the savanna woodlands of Africa (Boffa, 1999; Hall et al., 1996) in terms of socio-economic potential and ecological functions (Teklehaimanot, 2004; Sanou et al., 2004). The pulp can be eaten as a snack or processed into juice while the butter extracted from the dried kernels may be used as vegetable oil, manufacturing of skin care products and in pharmaceutical as well as confectionery industries (Kelly et al., 2004; Lamien et al., 2007). There is growing international demand for Shea butter products, especially in chocolate and cosmetic industry that has made Shea butter a flagship export commodity for many African countries (Teklehaimanot, 2004). About 350,000 metric tons of Shea butter are exported annually from Africa while 150,000 metric tons are consumed locally (http://www.globalshea.com).

Few studies have assessed the factors that influence fruit production. Most previous studies focused on the ecology and growth (Von Maydell, 1990), distribution and spatial patterns in relation to farmers' practices (Maranz and Wiesman, 2003) seasonal variation of phenology (Okullo et al., 2004a), impacts of land

Corresponding Author: Patrick Byakagaba, Department of Environment Management, Makerere University, P.O. Box 7062, Kampala, Uganda 
management regimes on flowering phenology (Kelly, 2007), population structure and land use types (Byakagaba et al., 2011) and human influence on genetic structure (Kelly et al., 2004). It is only Lamien et al. (2007) who developed Shea Fruit Prediction Models based only on dendrometric traits in Burkina Faso. The models developed were not only site specific but did not explore the influence of other important variables such as land use type (Boffa, 1999) on fruit yield.

Quantitative studies on fruit yield in $V$. paradoxa were also done in Benin by Kakai et al. (2011) however, they only focused on influence of climatic gradient. Studies (Boffa, 1999; Maranz and Wiesman, 2003) show that land management regime is an important predictor variable for any studies on $V$. paradoxa because humans influence the productivity of this tree through selecting particular trees of this species and land use practices.

In their studies in Northern Uganda Okullo et al. (2004b) reported that trees in cultivated areas have better fruit yield than fallows however, this was based on farmers perceptions. Quantitative data are therefore required for predicting fruit yield in $V$. paradoxa based on dendrometric traits and land use practices. Studies (Bayala et al., 2008; Boffa, 1995; Hall et al., 1996; Lovett, 2000 ) showed that fruiting in $V$. paradoxa may be cyclic but did not explore the possible reasons for this phenomenon hence spatial and temporal patterns need to be further investigated. Data on fruit yield dynamics is vital for determination of sustainable harvesting levels and planning the Shea industry. The aim of this study was to assess $V$. paradoxa fruit yield in relation to dendrometric traits and land use practices.
Fruit yield in this study refers to the number of fruits on each tree. Researchers determined the differences in fruit yield between land use types, between successive years and size of the trees. Researchers also developed fruit yield prediction models based on dendrometric traits and land use types.

We hypothesised that there is no inter-annual variability in fruit yield and that land use practices and dendrometric traits do not influence fruit yield in $V$. paradoxa. Other studies done in West Africa (Bayala et al., 2008; Lamien et al., 2007; Hall et al., 1996) posit that that there is inter-annual variability in fruit yield however, the pattern in Eastern Africa is yet to be known. The influence of dendrometric traits of $V$. paradoxa on fruit yield have been studied in West African Shea parklands (Bayala et al., 2008; Lamien et al., 2007) however, there are inconsistencies among various researchers hence, the need for more studies to have a better understanding of the relationship. Studies on other savanna tree species (Venter and Witkowski, 2011; Kimondo et al., 2011) show that land use influences fruit yield however, quantitative studies to confirm the trends of land use influence on fruit yield of $V$. paradoxa have not been done.

\section{MATERIALS AND METHODS}

Study area: The study was carried out in the Vitellaria savannas of Uganda in the districts of Katakwi ( $\left.1^{\circ} 53^{\prime} 28^{\prime \prime} \mathrm{N}, 33^{\circ} 57^{\prime} 58^{\prime \prime} \mathrm{E}\right)$, Lira (2 $\left.2^{\circ} 4^{\prime} 6^{\prime \prime} \mathrm{N}, 32^{\circ} 54^{\prime} 35^{\prime \prime} \mathrm{E}\right)$, Moyo $\left(3^{\circ} 37^{\prime} 41^{\prime \prime} \mathrm{N}, 31^{\circ} 45^{\prime} 13^{\prime \prime} \mathrm{E}\right)$ and Nakasongola $\left(1^{\circ} 18^{\prime} 32^{\prime \prime} \mathrm{N}\right.$, $32^{\circ} 27^{\prime} 23^{\prime \prime} \mathrm{E}$ ) (Fig. 1). The sites are flat except Katakwi

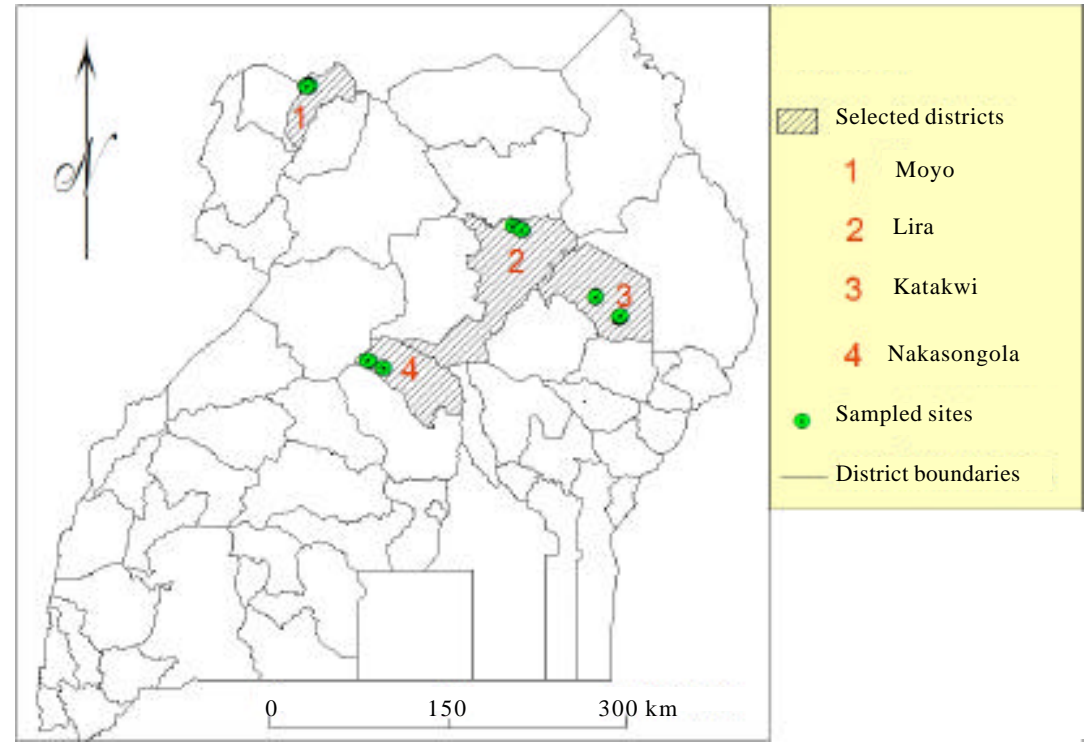

Fig. 1: Map of Uganda showing the location of study sites (Byakagaba et al., 2011) 
that has some plateaus. The mean annual rainfall ranges between $500-1600 \mathrm{~mm}$ and they experience bimodal rainfall regime. The soils in these sites vary from sandy, loamy and clay with a $\mathrm{pH}$ ranging from 5.5-6.5. These sites are mainly characterised by shallow soil profiles with low moisture content in most part of the year except during the wet season. The vegetation is dominated by Vitellaria paradoxa and other savanna woodland species such as Acacia sp., Terminalia sp. and Combretum sp. (Langdale-Brown et al., 1964). The major economic activities include subsistence agriculture, livestock rearing, charcoal burning and Shea butter fruit collection or processing.

Sampling design: One site was subjectively selected in each district based on presence of Vitellaria paradoxa within fallow and cultivated land use types. The two land use types dominate Vitellaria savannas (Byakagaba et al., 2011; Okullo et al., 2004a; Boffa, 1999). Fallow land was categorised as old or young. This is based on the duration the land has been under fallow. Old fallow is a piece of land that has not been cultivated for $>10$ years; young fallows are 3-6 years old, cultivated land (current fields) are areas covered by annual crops at the time of study. In Nakasongola no current fields with $V$. paradoxa were encountered. Old fallows are usually covered by dense vegetation compared to young fallows and current fields, respectively.

Fallows facilitate tree recovery through re-growth of stumps or germination of the seeds (Augusseau et al., 2006). Current fields are covered by low tree cover because of high level of disturbance associated with growing of annual crops, especially due to weeding. Four square plots of $50 \times 50 \mathrm{~m}$ were established within each land use type. The location of the first plot was randomly chosen and subsequent plots were systematically established along a transect at intervals of $100 \mathrm{~m}$.

\section{Data collection}

Fruit yield assessment: Within each of the $50 \times 50 \mathrm{~m}$ plots, three fruiting Vitellaria paradoxa trees were selected randomly from each plot, tagged and fruit yield assessed over two fruiting seasons (year 2009-2010 and 2010-2011). Fruit yield data were collected between the months of May and June just before the fruits started dropping (peak of fruiting). Fruit yield was measured following the Randomised Branch Sampling Method (Jessen, 1955). Sampling of branches considered the first forking of the stem. Each of the branches was labelled and four other succeeding branches along the path of each main branch were selected randomly. Each selected branch was followed to the terminal segment and fruits counted. The number of fruits for each selected branch was derived by dividing the number of fruits observed at the terminal of the path by the probabilities (number of forks) along the path. The pooled fruit yield estimate was determined based on the average of the totals from the selected branches of each tree.

Collection of data on dendrometric traits: The following dendrometric traits were measured for each sample tree: height, crown diameter and Diameter at Breast Height (DBH). The DBH was measured at $1.3 \mathrm{~m}$ above ground using a diameter tape. Height was measured using a SUUNTO clinometer. Crown diameter was measured using a $100 \mathrm{~m}$ tape by two people each standing at the extreme part of the crown in the North-South and East-West directions determining the length on the ground. The average of North-South and East-West distances was considered as crown diameter. Height at first forking of the stem was measured using a tape. The number of stems at first forking of the main stem was also recorded.

Data analysis: The Kruskal-Wallis analysis of ranks was used to test differences in fruit yield between the three land use types. It is a nonparametric test used to determine whether more than two groups of ordinal data differ (Conover, 1999). The inter- annual variability in fruit yield was analysed using Mann-Whitney $U$ test which is a non-parametric test that is used to test whether two samples of ordinal data differ (ibid). Pearson correlation coefficients were calculated to test for any association between dendrometric traits of the trees and fruit yield (Schrekenberg, 1996; Kimondo et al., 2011). All the tests were done using Minitab Software (Minitab Inc. Pennsylvania, USA).

Fruit yield prediction models based on dendrometric variables and land use type were developed using Poisson Regression Analyses considering that fruit yield was collected as count data (Evans et al., 1988). The dendrometric variables were tested for multi-collinearity using Pearson correlation coefficients prior to the regression analyses. Variables with the highest correlation coefficient with fruit yield were retained in situations where multi-collinearity was observed.

\section{RESULTS}

Fruit yield in relation to land use practices: There was a significant difference in fruit yield among the different land use types in 2009-2010 fruiting season but not in 2010-2011 fruiting season. Current fields and young 
Res. J. Applied Sci., 7 (2): 92-99, 2012

Table 1: Mean seasonal (years 2009-2010 and 2010-2011) fruit yield among different land use types within the four study sites in Uganda Fruit yield (2009-2010) Fruit yield (2010-2011)

\begin{tabular}{|c|c|c|c|c|c|c|}
\hline \multirow[b]{2}{*}{ Study sites } & \multicolumn{3}{|c|}{ Fruit y 1eld (2009-2010) } & \multicolumn{3}{|c|}{ Fruit y 1eld (2010-2011) } \\
\hline & Old fallow & Young fallow & Current field & Old fallow & Young fallow & Current field \\
\hline Katakwi & $141.5 \pm 30.3$ & $539.0 \pm 135$ & $207.9 \pm 36.8$ & $921.0 \pm 299.0$ & $1349 \pm 328$ & $1190 \pm 281$ \\
\hline Lira & $202.0 \pm 81.0$ & $30.9 \pm 17.40$ & $210.8 \pm 65.1$ & $545.0 \pm 158.0$ & $259 \pm 112$ & $588 \pm 198$ \\
\hline Moyo & $274.5 \pm 54.6$ & $191.8 \pm 85.5$ & $131.1 \pm 29.4$ & $652.0 \pm 312.0$ & $792 \pm 204$ & $673 \pm 182$ \\
\hline Nakasongola & $41.5 \pm 14.6$ & $12.5 \pm 5.52$ & - & $92.3 \pm 20.40$ & 0 & - \\
\hline
\end{tabular}

Table 2: Fruit yield in the 2 years of fruit collection within the four study sites in Uganda

\begin{tabular}{lcc}
\hline Sites & Median in 2009-2010 & Median in 2010-2011 \\
\hline Katakwi & 194 & $818^{*}$ \\
Lira & 84 & $328^{*}$ \\
Moyo & 140 & $463^{*}$ \\
Nakasongola & 16 & 22 \\
\hline
\end{tabular}

*Significant at $\mathrm{p}<0.05$

Table 3: Correlation between dendrometric traits and fruit yield within the four study sites in Uganda

\begin{tabular}{lccccc}
\hline & Sites & & & & \\
$\begin{array}{l}\text { Dendrometric } \\
\text { trait }\end{array}$ & Katakwi & Lira & Moyo & Nakasongola & $\begin{array}{c}\text { Aggregated } \\
\text { data }\end{array}$ \\
\hline DBH & 0.168 & $0.246^{*}$ & $0.391^{*}$ & $0.280^{*}$ & $0.381^{*}$ \\
Height & 0.102 & 0.191 & $0.315^{*}$ & $0.491^{*}$ & $0.217^{*}$ \\
$\begin{array}{l}\text { Height at } \\
\text { first forking }\end{array}$ & -0.024 & 0.191 & $0.226^{*}$ & $0.414^{*}$ & 0.086 \\
$\begin{array}{l}\text { No. of branches } \\
\text { at first forking }\end{array}$ & -0.113 & 0.135 & 0.188 & -0.168 & $0.128^{*}$ \\
Crown diameter & $0.290^{*}$ & $0.313^{*}$ & $0.258^{*}$ & $0.383^{*}$ & $0.376^{*}$ \\
\hline *Significant at $\mathrm{p}<0.05$ & & & &
\end{tabular}

fallows registered high fruit yield than old fallows in both seasons of data collection. The means of fruit yield under each land use type are shown in Table 1.

Inter-annual variability in fruit yield: There was generally, a significant difference in fruit yield between 2 years of data collection (2009-2010 and 2010-2011). Fruit yield at each site in each year of data collection are shown in Table 2.

Relationship between dendrometric traits and fruit yield within the four selected study sites in Uganda: The DBH and crown diameter were generally significantly correlated to fruit yield. The correlation between the number of branches at first forking, total height, height at first forking and fruit yield was generally weak compared to the correlation between $\mathrm{DBH}$, crown diameter and fruit yield. Height at first forking point was not significantly correlated with fruit yield when the data of all sites was aggregated. The correlation coefficients for each dendrometric trait and fruit yield are shown in Table 3. Generally, the correlation between dendrometric traits and fruit yield was weak $(r<0.4)$.

Fruit Yield Prediction Models: The DBH, land use type and number of branches at first forking point of the main
Table 4: Parameter estimates for the models in Katakwi, Lira, Moyo and Nakasongola

\begin{tabular}{llcccc}
\multicolumn{7}{c}{ Nakasongola } \\
\hline \multicolumn{7}{c}{ Parameter estimates } \\
Sites & Intercept & fallow & $\begin{array}{l}\text { Young } \\
\text { fallow }\end{array}$ & DBH & $\begin{array}{l}\text { No. of branches at } \\
\text { first forking point }\end{array}$ \\
\hline Katakwi & $5.744^{*}$ & $-0.145^{*}$ & $0.378^{*}$ & $0.019^{*}$ & $-0.157^{*}$ \\
Lira & $4.65^{*}$ & $-0.225^{*}$ & $-1.029^{*}$ & $0.028^{*}$ & - \\
Moyo & $3.478^{*}$ & $0.740^{*}$ & $0.844^{*}$ & $0.038^{*}$ & - \\
Nakasongola & 2.915 & $2.134^{*}$ & - & $0.020^{*}$ & $-0.787^{*}$ \\
\hline
\end{tabular}

*Significant at $\mathrm{p}<0.05$

stem were used in the Poisson Regression Analyses leaving out other variables due to multi-collinearity. The parameter estimates for the models for each site are shown in Table 4. The Poisson Regression Models for each site are as follows:

$\operatorname{lnlog}$ of fruit yield in Katakwi $=5.744-0.145 \mathrm{OF}+0.378 \mathrm{YF}+$ $0.019 \mathrm{DBH}-0.157 \mathrm{NB}$

lnlog of fruit yield in Lira $=4.65-0.225 \mathrm{OF}-1.029 \mathrm{YF}+$ $0.028 \mathrm{DBH}$

$\ln \log$ of fruit yield in Moyo $=3.478+0.74 \mathrm{OF}+$ $0.844 \mathrm{YF}+0.038 \mathrm{DBH}$

$\ln \log$ of fruit yield Nakasongola $=2.915+2.134 \mathrm{OF}+$ $0.02 \mathrm{DBH}-0.787 \mathrm{NB}$ Where:

$\mathrm{OF}=$ Old Fallow

$\mathrm{YF}=$ Young Fallow

$\mathrm{DBH}=$ Diameter at Breast Height

NB $=$ Number of Branches at first point of branching

It is predicted that fruit yield in Katakwi would be 1.2 times ( $\exp (0.145)$ ) lower in old fallow compared to current fields while holding other variables constant. Fruit yield in young fallow is predicted to be 1.6 (exp (0.378)) times higher than current fields while holding other variables constant, increase in DBH by $1 \mathrm{~cm}$ would result into $1(\exp (0.019))$ time increase in the fruit yield assuming all factors remain constant while single unit increase in number of branches at first forking point would result into decrease of fruit yield by $1.2(\exp (0.157))$ times. 
It is predicted that fruit yield in Lira would be $1.3(\exp (0.225))$ times lower in old fallow compared to current fields while holding other variables constant while predicted fruit yield in young fallow is expected to be $2.8(\exp (1.029))$ times lower than in current fields while holding other variables constant. Increase in DBH by $1 \mathrm{~cm}$ would result into $1(\exp (0.028))$ time increase in the fruit yield assuming all factors remain constant. Fruit yield in old fallow of Moyo is expected to be $2.1(\exp (0.74))$ times higher than in current fields while holding other variables constant while predicted fruit yield in young fallow is expected to be 2.3 (exp (0.844)) higher than in current fields while holding other variables constant. Increase in DBH by $1 \mathrm{~cm}$ would result into $1(\exp (0.038))$ time increase in fruit yield assuming all the other variables remain constant. It is predicted that fruit yield in Nakasongola would be $8.5(\exp (2.134))$ times higher in old fallows than in young fallow while holding other variables constant. Increase in DBH by $1 \mathrm{~cm}$ would result into 1 $(\exp (0.02))$ time increase in fruit yield assuming all factors remain constant. Increase in number of branches at first forking point would result into expected fruit yield to decrease by $2.2(\exp (0.787))$ times assuming all variables remain constant.

\section{DISCUSSION}

Fruit yield in relation to land use practices: The present findings corroborate Venter and Witkowski (2011) who found that fruit yield in savanna tree species tends to be high in human modified sites like cultivated areas and young fallows compared to areas that have been under fallow for along time and have characteristics of undisturbed landscapes. This phenomenon could be attributed to sparse vegetation in the current fields and young fallows (pers.obs.) which may result in to reduced inter-plant competition hence increasing availability of limited growth resources necessary for the increase in fruit yield in these land use types compared to old fallows. The sparse vegetation in current fields may also be due to regular weeding that is carried out by farmers when growing crops.

Trees in current fields are usually safe from wild fires because of the low fuel load under this land use type and fire protection provided by farmers hence they attain maximum fruiting compared to those in old fallows which are rarely protected from fires (Okullo et al., 2004b). The study therefore, confirms that maximum fruit yield in $V$. paradoxa is achieved in current fields and young fallows which are characterized by sparse vegetation cover and protected from incessant wild fires. This is probably because $V$. paradoxa prefers sites with less competition and protection from incessant fires in order to attain maximum fruit production (Hall et al., 1996).

Inter-annual variability in fruit yield: The inter-annual variability in fruit yield is reported else where in literature (Bayala et al., 2008; Boffa, 1995; Hall et al., 1996). This trend may be explained by the differences in weather conditions in the periods the data were collected. Area within the Shea belt of Uganda experienced heavy rainfall and floods in the years 2007 and 2008 (MWE, 2011). This probably affected flowering of Shea butter trees in the 2009-2010 fruiting season negatively resulting in relatively low fruit yields compared to the 2010-2011 fruiting season. High precipitation is associated with reduction in flowering and fruiting in V. paradoxa (Okullo et al., 2004a) which explains the present results. High precipitation may lead to the abortion of flowers. The high inter-annual variability in fruit yield complicates predictions that are necessary to establishing sustainable harvesting rates. Thus fruiting in Shea butter trees is confirmed to be cyclic but long terms studies are required to identify patterns of fruit yield (Lovett, 2000).

Relationship between dendrometric traits and fruit yield: The diameter at breast height, crown diameter and height all exhibited a weak positive correlation with fruit yield of individual trees ( $r$-values $<0.5$ ) however, this to some extent is contrary to Lamien et al. (2007) who did not find significant correlation between stem tree diameter or height with fruit yield but found significant correlation with crown diameter. Similarly, Schrekenberg (1996), Miller and Dietz (2004) and Kimondo et al. (2011) found positive correlation between stem diameter and fruit yield. Larger and taller trees are considered to have high fruit yield because as DBH and height increase it implies that the tree is drawing closer to maturity when maximum fruiting is expected. Shea butter trees attain maximum fruiting at 20 to $>50$ years (Okullo et al., 2004a) and therefore since increase in stem diameter and height imply increase in age, fruiting would increase with an increase in these variables.

Large crown diameters indicate large numbers of potential fruiting branches and subsequently fruit yield (Foster, 2008). Bayala et al. (2008) however did not find any significant difference in fruit yield when the crown of the trees assessed was reduced by half-pruning. This may be due to the differences in the canopy shapes of trees assessed. Generally, the Shea butter trees in West Africa are dominated by broom-shaped or oblong canopies (Diarrassouba et al., 2007) unlike Eastern Africa which is dominated by spherical-shaped canopies (Okullo et al., 
$2004 a$, b). Reducing crown diameter in trees with spherical-shaped canopies reduces the surface area for light penetration necessary for fruiting of most branches on an individual tree and vice versa (Warrington et al., 1996). Reducing crown diameter in broom or oblong-shaped canopies has no significant influence on light intercepted by the tree hence fruit yield may not necessarily change when crown diameter is manipulated.

Prediction of fruit yield: The models show that the likelihood of fruit yield increase was high in current fields than fallows. This is expected considering that current fields in Shea belt of Uganda are usually characterized by very low tree cover of other species (pers. observ.) that would increase inter-plant competition to jeopardize the ability of Shea butter trees to fruit to their full potential. Although increase in $\mathrm{DBH}$ was predicted to increase the likelihood of fruit yield increase; its influence was minimal compared to other variables. This is probably because all trees sampled were mature and therefore had reached the size for maximum fruiting capacity hence differences in fruit could not be very strongly associated to size of the tree.

The models show that the likelihood of fruit yield to decrease was high in trees that had many branches at first forking point of the stem compared to those with few. This is probably because increase in number of branches increases competition for resources within an individual tree (Karlsson et al., 2006) and therefore the limited resources for the tree are prioritized for critical physiological processes of the plant such as leaf formation instead of fruiting (Karlsson and Mendez, 2005).

More so, trees with many branches at the first forking point had small crown diameters with thick canopies compared to those with few branches (Byakagaba) and this could have reduced the surface for light penetration (Bayala et al., 2008) yet adequate light is critical for flower development and subsequent fruiting process (Lakso and Robinson, 1997). Farmers ought to be advised to maintain trees with few branches at the first forking point because they develop large crowns with open canopies which allow light penetration necessary for maximum fruiting as shown from the present study.

\section{CONCLUSION}

The study shows that land use influences fruit yield in Shea butter tree however, its influence varies with site. This study has confirmed that human modified habitats like the current field and young fallows have better fruit yield compared to sites that have been left under fallow for a long time. Researchers found that there was high inter-annual variability between the 2 years of fruit data collection and we associate this to the high rainfall that was received in the preceding year before data collection commenced. This confirms that fruiting in Shea butter trees is cyclic and is most likely influenced by rainfall distribution in the preceding year.

Dendrometric traits influence fruit yield however, their influence is weak compared to land use type on fully mature trees. It is possible to construct fruit yield prediction models in Shea butter tree however, it is difficult to build models that can be applicable to different sites. The study confirms the importance of regionspecific fruit yield studies considering that the influence of the explanatory variables was different for various sites and therefore developing one model for all sites would increase the error term in model constructed. Before the models can be applied in the management of Shea parklands; there is need for further assessments over a long period considering that there is annual variation in fruit production in Shea butter trees as the present study has shown.

\section{ACKNOWLEDGEMENTS}

Researchers thank the research assistants notably Patrick Abwango, Musa Peter, Paul Omongin, Joel Buyinza, Patrick Anyama and Elongat Jonathan. Researchers are indebted Carnegie Cooperation of New York and European Union (INNOVKAR project) for funding the field work. We are equally grateful to German Academic Exchange Service that provided logistical support to Patrick Byakagaba $(\mathrm{PhD}$ candidate) during data collection and preparation of the manuscript.

\section{REFERENCES}

Augusseau, X., P. Nikiema and E. Torquebiau, 2006. Tree biodiversity, land dynamics and farmers strategies on the agricultural frontier of southwestern Burkina faso. Biodivers. Conserv., 16: 613-630.

Bayala, J., S.J. Quedraogo and Z. Teklehaimanot, 2008. Rejuvenating indigenous trees in agroforestry parkland systems for better fruit production using crown pruning. Agroforestry Syst., 72: 187-194.

Boffa, J.M., 1995. Productivity and management of agroforestry parklands in the Sudan zone of Burkina Faso, West Africa. Ph.D. Thesis, Purdue University, West Lafayette, Indiana, USA. 
Boffa, J.M., 1999. Agroforestry Parklands in Sub-Saharan Africa: FAO Conservation Guide 34. Food and Agricultural Organization of the United Nations, Rome, Italy, ISBN: 9251043760, Pages: 230.

Byakagaba, P., G. Eilu, J.B.L. Okullo, S.B. Tumwebaze and E.N. Mwavu, 2011. Population structure and regeneration status of Vitellaria paradoxa (C.F.Gaertn.) under different land management regimes in uganda. Agric. J., 6: 14-22.

Conover, W.J., 1999. Practical Nonparametric Statistics. 3rd Edn., John Wiley and Sons, New York, ISBN: 978-0-471-16068-7, pp: 269-427.

Diarrassouba, N., N.D. Bup, C. Kapseu, C. Kouma and A. Sangare, 2007. Phenotypic diversity of Shea (Vitellaria paradoxa C.F. Gartn.) population across four Agro-ecological zones of Cameroon. J. Crop Sci. Biotechnol., 10: 233-240.

Evans, R.J., J. Boersma, N.M. Blachman and A.A. Jagers, 1988. The entropy of a poisson distribution: Problem 87-6. SIAM Rev., 30: 314-317.

Foster, M.S., 2008. Freeze-frame fruit selection by birds. Wilson J. Ornithol., 120: 901-905.

Hall, J.B. and J.R. Hindle, 1995. Epitypication of Vitellaria paradoxa C.F Gaertn (Sapotaceae). Taxon, 44: 409-410.

Hall, J.B., D.P. Aebischer, H.F. Tomlinson, E. OseiAmaning and J.R. Hindle, 1996. Vitellaria paradoxa: A monograph. School of Agricultural Sciences Publication No. 8. University of Wales, Bangor, UK., pp: 105.

Jessen, R.J., 1955. Determining the fruit count on a tree by randomised branch sampling. Biometrics, 11: 99-109.

Kakai, R.G., T.J.D. Akpona, A.E. Assogbadjo and O.G. Gaoue et al., 2011. Ecological adaptation of the shea butter tree (Vitellaria paradoxa C.F. Gaertn.) along climatic gradient in Benin, West Africa. Afr. J. Ecol., 49: 440-449.

Karlsson, P. S. and M. Mendez, 2005. The resource economy of plant reproduction.. Reproductive Allocation in Plants Academic Press, New York, USA., pp: 1-49.

Karlsson, P.S., M. Anderssson and B.M. Svensson, 2006. Relationships between fruit production and branching in monocarpic shoot modules of Rhododendron lapponicum. Ecoscience, 13: 396-403.

Kelly, B.A., 2007. Impact of agroforestry practices on the flowering phenology of Vitellaria paradoxa in parklands in Southern Mali. Agrofor. Syst., 71: 67-75.

Kelly, B.A., O. Hardy and J.M. Bouvet, 2004. Temporal and spatial genetic dynamics in Vitellaria paradoxa (shea tree) in an agroforestry system in Southern Mali. Mol. Ecol., 13: 1231-1240.
Kimondo, J.M., C.A. Okia, J.G. Agea, R.A.A. Abohassan, J. Mulatya and Z. Teklehaimanot, 2011. Estimating fruit yield from Vitex payos (Lour) Merr. In semi-arid eastern province of Kenya: Application of allometric equations. Res. J. Applied Sci., 6: 153-162.

Lakso, A.N. and T.L. Robinson, 1997. Principles of orchard systems management optimizing supply, demand and partitioning in apple trees. Acta Hortic., 451: 405-416.

Lamien, N., M. Tigabu, S. Guinko and P.C. Oden, 2007. Variations in dendrometric and fruiting characters of Vitellaria paradoxa population and multivariate models for estimation of fruit yield. Agroforestry Syst., 69: 1-11.

Langdale-Brown, I., H.A. Osmaston and J.G. Wilson, 1964. The Vegetation of Uganda and its Bearing on Land use. Government of Uganda, Entebbe, pp: 1-159.

Lovett, P.N., 2000. The genetic diversity of the Shea nut tree (Vitellaria paradoxa) in the farming systems of northern Ghana. Ph.D. Thesis, University of Southampton, Southampton, UK.

MWE, 2011. Ministry of water and environment. Water and Environment Sector Performance Report. Kampala, Uganda. http://www.mwe.go.ug/

Maranz, S. and Z. Wiesman, 2003. Evidence for indigenous selection and distribution of the Shea tree, Vitellaria paradoxa and its potential significance to prevailing parkland savanna tree patterns in sub-Saharan Africa north of the equator. J. Biogeogr., 30: 1505-1516.

Miller, K.E. and J.M. Dietz, 2004. Fruit yield, not dbh or fruit cown volume, correlates with time spent feeding on fruits b wild Leontopithecus rosalia. Int. J. Primatol., 25: 27-39.

Okullo, J.B.L., J. Obua and G. Okello, 2004b. Use of indigenous knowledge in predicting fruit production of shea butter tree in agroforestry parklands of North-Eastern Uganda. Uganda J. Agric. Sci., 9: $360-366$.

Okullo, J.B.L., J.B. Hall and J. Obua, 2004a. Leafing, flowering and fruiting of Vitellaria paradoxa subsp. nilotica in savanna parklands in Uganda. Agroforestry Syst., 60: 77-91.

Sanou, H., S. Kambou, Z. Teklehaimanot, M. Dembele and H. Yossi et al., 2004. Vegetative propagation of Vitellaria paradoxa by grafting. Agroforestry Syst., 60: 93-99.

Schrekenberg, K., 1996. Forests, fields and markets: A study of indigenous tree products in woody savanna of the Bassila region, Benin. Ph.D. Thesis, University of London, United Kingdom, 
Teklehaimanot, Z., 2004. Exploiting the potential of indigenous agroforestry trees: Parkia biglobosa and Vitellaria paradoxa in sub-Saharan Africa. Agroforestry Syst., 61: 207-220.

Venter, S.M. and T.F. Witkowski, 2011. Baobab (Adansonia digitata $\mathrm{L}$.) fruit production in communal and conservation land-se types on Southern Africa. For. Ecol. Manage., 261: 630-639.
Von Maydell, H.J., 1990. Trees and Shrubs of the Sahel: Their Characteristics and their Utilizations.. Margraf, Weikersheim, Germany.

Warrington, I.J, C.J. Syanley, D.S. Tustin, P.M. Hirst and W.M. Cashmore, 1996. Light transmission, Yield distribution and fruit quality in six tree canopy forms of 'Granny smith' Apple. J. Tree Fruit Produc., 1: $27-54$. 